\title{
Increase of soybean yield through agricultural practices in Central Brazil
}

\author{
Denise Prevedel Capristo ${ }^{1 *} \oplus$, Gessí Ceccon$^{2} \oplus$, Ricardo Fachinelli ${ }^{1} \oplus$, Carla Medianeira Giroletta dos Santos ${ }^{1} \oplus$ \\ ${ }^{1}$ Universidade Federal da Grande Dourados, Dourados, MS, Brasil. E-mail: denise_prevedel@hotmail.com; rfachinell@hotmail.com; carlagiroletta@icloud.com \\ ${ }^{2}$ Embrapa Agropecuária Oeste, Dourados, MS, Brasil. E-mail: gessi.ceccon@embrapa.br
}

ABSTRACT: The soybean-second-crop corn succession is the main grain production system in the Midwest region of Brazil; however, the greatest obstacle of this system is the low soil cover rates. Thus, this study aimed to evaluate the influence of inoculation and co-inoculation of Bradyrhizobium japonicum and Azospirillum brasilense on soybean yield in succession to autumn-winter crops. The experiment was carried out in Dourados, Mato Grosso do Sul during the 2018-2019 and 2019-2020 harvests. The experimental design was randomized blocks with treatments in a $4 \times 3$ factorial scheme, with four replications. The four autumn-winter crops constituted the first factor: single corn, corn-brachiaria intercropping, Urochloa ruziziensis established since 2013, and U. ruziziensis established since 2016. The second factor was based on inoculation treatments (without inoculation, inoculation of $B$. japonicum, and co-inoculation of $B$. japonicum with $A$. brasilense). The Urochloa ruziziensis cultivated in autumn-winter contributes to increasing the soybean grain yield in succession. Co-inoculation of Bradyrhizobium japonicum with Azospirillum brasilense complements biological nitrogen fixation, contributing to soy development.

Key words: biological nitrogen fixation; Glycine max L. Merr.; no-tillage; Urochloa

\section{Aumento da produtividade da soja através de práticas agrícolas no Brasil Central}

RESUMO: A sucessão soja-milho safrinha é o principal sistema de produção de grãos da região Centro-Oeste do Brasil, no entanto o maior entrave deste sistema está nos baixos índices de cobertura do solo. Desta forma, objetivou-se avaliar a influência da inoculação e coinoculação de Bradyrhizobium japonicum e Azospirillum brasilense na produtividade da soja em sucessão a cultivos de outono-inverno. O experimento foi realizado nas safras 2018-2019 e 2019-2020, em Dourados, Mato Grosso do Sul. $O$ delineamento experimental foi de blocos casualizados com os tratamentos em esquema fatorial $4 \times 3$, com quatro repetições. O primeiro fator foi constituído pelos quatro cultivos de outono-inverno: milho solteiro, consórcio milho-braquiária, Urochloa ruziziensis estabelecida desde 2013 e U. ruziziensis estabelecida desde 2016 e o segundo, pelos tratamentos com inoculação (sem inoculação, inoculação de $B$. japonicum e coinoculação de $B$. japonicum com $A$. brasilense). A Urochloa ruziziensis cultivada no outono-inverno contribui para o aumento da produtividade de grãos da soja em sucessão. A coinoculação de Bradyrhizobium japonicum com Azospirillum brasilense complementa a fixação biológica de nitrogênio (FBN) contribuindo no desenvolvimento da soja.

Palavras-chave: fixação biológica de nitrogênio; Glycine max L. Merr.; plantio direto; Urochloa

\footnotetext{
* Denise Prevedel Capristo - E-mail: denise_prevedel@hotmail.com (Corresponding author)

Associate Editor: Adônis Moreira
} 


\section{Introduction}

Soybean (Glycine max (L.) Merr.) occupies a prominent economic position in Brazil and the world due to its potential productivity. The predominant crop production in the Midwest region of Brazil is based on the soybean-corn succession, which tends to provide greater soybean exposure to adverse effects of the climate due to the low soil cover levels.

Given the soybean importance, its yield can still be substantially increased since a large part of production losses are caused by water deficiency (Sentelhas et al., 2015; Battisti et al., 2018). One way to minimize the negative impacts of the soybeancorn succession is to introduce autumn-winter cover crops.

For having high soil covering capacity, forage species of the Urochloa genus (sin. Brachiaria) have been widely used in intercropping with off-season corn. This method provides climatic risk reduction due to the soil remaining covered for a longer time, greatly benefitting the soybean grown in succession (Ceccon et al., 2014). Besides the use of cover crops, nitrogen-fixing bacteria-based inoculants use is a lowcost alternative that has been researched to increase crop yield and reduce the use of nitrogen fertilizers (Bashan et al., 2014). For example, in soybeans, the crop nitrogen supply can be obtained through biological atmospheric nitrogen fixation (BNF) (Hungria et al., 2015a).

Another strategy used to increase crop yield is based on co-inoculation or mixed inoculation of bacteria of the genus Bradyrhizobium with bacteria that promote the Azospirillum genus plant growth (Hungria et al., 2015b; Zuffo et al., 2016). The co-inoculation technique of microorganisms with different functions can be considered economically viable and environmentally sustainable for improving crop performance (Zeffa et al., 2020).

Due to the soybean-off-season corn succession being the main agricultural production system in the Midwest region of Brazil and the need to increase the yield capacity of soybeans, this study aimed to evaluate the Bradyrhizobium japonicum and Azospirillum brasilense inoculation and co-inoculation influence on soybean yield in succession to autumn-winter crops.

\section{Materials and Methods}

The experiment was carried out in the 2018-2019 and 2019-2020 harvests, in the experimental area of Embrapa Agropecuária Oeste, in Dourados, Mato Grosso do Sul, at coordinates $22^{\circ} 16^{\prime} \mathrm{S}$ and $54^{\circ} 49^{\prime} \mathrm{W}$ at $408 \mathrm{~m}$ of altitude. The soil was identified as a Latossolo Vermelho distroférrico, with a very clayey texture, according to the criteria of the Brazilian Soil Classification System (Santos et al., 2018) and clayey Rhodic Hapludox (Oxisol) according to the Soil Taxonomy (USDA, 1999), with the following characteristics in the $0-0.20 \mathrm{~m}$ layer: $\mathrm{pH}$ $\left(\mathrm{CaCl}_{2}\right.$ 0, $\left.01 \mathrm{~mL}^{-1}\right)=6.2$; base saturation $(\mathrm{V} \%)=79.3$; OM $\left(\mathrm{g} \mathrm{kg}^{-1}\right)$ $=37.9 ; \mathrm{P}\left(\mathrm{mg} \mathrm{dm}^{-3}\right)=57.3 ; \mathrm{K}^{+}\left(\mathrm{cmol} \mathrm{dm}^{-3}\right)=1.0 ; \mathrm{Ca}^{2+}(\mathrm{cmol} \mathrm{dm}$ $\left.{ }^{3}\right)=6.5 ; \mathrm{Mg}^{2+}\left(\mathrm{cmol}_{c} \mathrm{dm}^{-3}\right)=2.8$ and $\mathrm{Al}^{3+}\left(\mathrm{cmol}_{\mathrm{c}} \mathrm{dm}^{-3}\right)=2.7$; sand $\left(\mathrm{g} \mathrm{kg}^{-1}\right)=136$; silt $\left(\mathrm{g} \mathrm{kg}^{-1}\right)=151$, and clay $\left(\mathrm{g} \mathrm{kg}^{-1}\right)=713$.

The experimental area has been managed under a notillage system (NTS) for 15 years, in a crop succession scheme for seven years; in the autumn-winter, off-season corn, Urochloa ruziziensis, and corn intercropped with $U$. ruziziensis were grown, and in the summer, soybean was cultivated.

The experimental design was randomized blocks with treatments arranged in a $4 \times 3$ factorial scheme, with four replications. The first factor consisted of the four autumnwinter crops: single corn, corn-brachiaria intercropping, $U$. ruziziensis established since 2013, and U. ruziziensis established since 2016. The second factor was based on the inoculation treatments (without inoculation, Bradyrhizobium japonicum inoculation, and co-inoculation of $B$. japonicum with Azospirillum brasilense).

During the cultivation of soybeans in the 2018-2019 and 2019-2020 seasons, the meteorological data were obtained at the Embrapa Agropecuária Oeste Meteorological Station, close to the experimental area. During the experiments, the total rainfall was $673 \mathrm{~mm}$ in the 2018-2019 harvest and 552 $\mathrm{mm}$ in the 2019-2020 harvest (Figure 1).

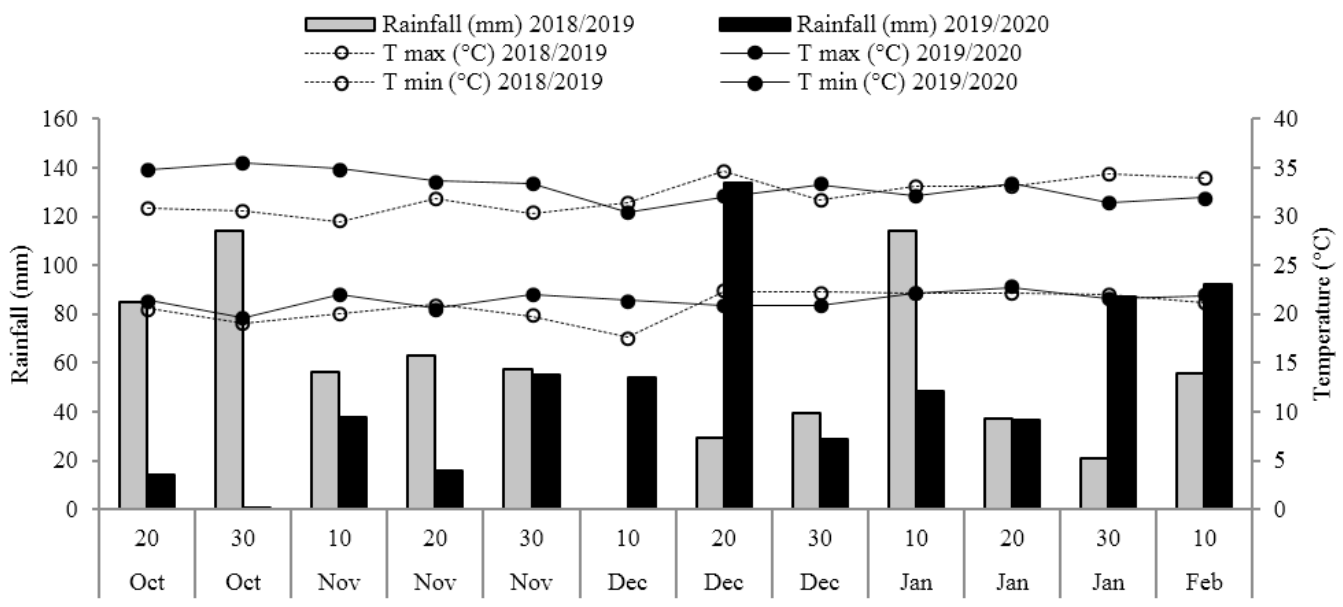

Source: (Embrapa, 2020).

Figure 1. Accumulated rainfall $(\mathrm{mm})$ and maximum and minimum temperatures $\left({ }^{\circ} \mathrm{C}\right)$ in ten-day periods, recorded during soybean cultivation in the 2018-2019 and 2019-2020 harvests, in Dourados, MS. 
The desiccation of the area was carried out 11 days before sowing, using glyphosate herbicide at a dose of $1.1 \mathrm{~kg} \mathrm{ha}^{-1}$ of acid equivalent, with a spray volume of $200 \mathrm{~L} \mathrm{ha}^{-1}$, in a tractor spray, for the control of weeds and brachiaria of autumnwinter crops. Before soybean sowing, chemical analysis of the soil was carried out for later correction of soil fertility following the crop technical recommendations.

The soybean was sown on October 15, 2018, in the 2018-2019 harvest and November 12, 2019, in the 20192020 harvest, on autumn-winter crops, in plots consisting of seven rows, spaced $0.45 \mathrm{~m}$ apart, $10 \mathrm{~m}$ in length. Twelve seeds were distributed per meter to establish 260 thousand plants per hectare. The cultivar used was BRS 1003 IPRO, transgenic (tolerant to glyphosate and with intact RR2 PRO TM technology), early cycle, undetermined growth, and maturation group 6.3, moderately resistant to the Meloidogyne javanica gall nematode (Embrapa, 2016).

The seeds were inoculated in the sowing furrow, with strains of $A$. brasilense AbV5 and AbV6 with $2 \times 10^{8} \mathrm{CFU} \mathrm{mL}$ 1 , and with $B$. japonicum with strains SEMIA 587 and SEMIA 5080 with $6 \times 10^{1} \mathrm{CFU} \mathrm{g}^{-1}$, obtained from commercial products registered with the Ministry of Agriculture and Livestock (Mapa, 2011). The doses used were $100 \mathrm{~mL} 40 \mathrm{~kg}^{-1}$ seeds of

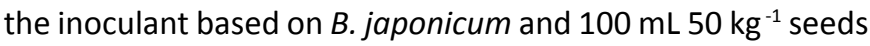
of the inoculant based on $A$. brasilense.

In the full flowering of soybeans (R2 stage), samples from the root system and shoot were collected in five plants per plot. The samples were washed in running water, and the root system was separated of the shoot to determine the number of nodules per plant (no. Plant ${ }^{-1}$ ), nodule dry mass (g plant ${ }^{-1}$ ), root dry mass (g plant ${ }^{-1}$ ), and shoot dry mass (g plant ${ }^{-1}$ ). These samples were dried in an oven with forced air circulation at $65^{\circ} \mathrm{C}$ for 72 hours, then the mass of plants and nodules was quantified in an analytical balance.

The physiological maturation of soybean plants occurred on February 8, 2019, and February 2, 2020, corresponding to the 2018-2019 and the 2019-2020 harvests, respectively. Parameters such as plant height $(\mathrm{cm})$, number of grains per pod, number of pods per plant, number of grains per plant were evaluated. The two central rows of three meters length in each experimental unit were collected and mechanically tracked. After the complete grain drying, grain yield $\left(\mathrm{kg} \mathrm{ha}^{-1}\right)$ and 100 -grain weight $(\mathrm{g})$ were determined, with a humidity correction to $13 \%$.

After complying with the assumptions of the analysis of variance (independence and normality of errors by the Shapiro-Wilk test and homoscedasticity of the treatment variances by the Bartlett test), the procedure was continued and, when a significant difference was observed, the means were compared by the Tukey test ( $p \leq 0.05)$.

\section{Results and Discussion}

There was a difference between the autumn-winter crops for the 100-grain weight $(\mathrm{g})$ and grain yield $\left(\mathrm{kg} \mathrm{ha}^{-1}\right)$ in the 2018-2019 harvest as well as for plant height $(\mathrm{cm})$, the 100 -grain weight $(\mathrm{g})$, and grain yield $\left(\mathrm{kg} \mathrm{ha}^{-1}\right)$ in the 20192020 harvest. Among the inoculation treatments, there was a significant difference in the shoot dry mass (g plant ${ }^{-1}$ ) in the 2018-2019 harvest and in the number of nodules per plant ( $\mathrm{n}$ o plant ${ }^{-1}$ ), nodule dry mass (g plant ${ }^{-1}$ ), root dry mass (g plant ${ }^{-1}$ ), shoot dry mass $\left(\right.$ g plant $^{-1}$ ), and plant height $(\mathrm{cm})$ in the 20192020 harvest. There was no significant interaction between autumn-winter crops and the inoculation (Table 1).

Table 1. Summary of analysis of variance for the number of nodules per plant (NNP), nodule dry mass (NDM), root dry mass (RDM), shoot dry mass (SDM), plant height (PH), number of grains per pod (NGPP), number of grains per plant (NGPPI), number of pods per plant (NPPPI), 100-grain weight (100W), and grain yield (PROD), of soybean grown on autumn-winter crops in the 2018-2019 and 2019-2020 harvests, Dourados, MS (2020).

\begin{tabular}{|c|c|c|c|c|c|c|c|c|c|c|c|}
\hline SV & DF & NNP & NDM & RDM & SDM & PH & NGPP & NPPPI & NGPPI & $100 W$ & YIELD \\
\hline & & \multicolumn{10}{|c|}{ 2018-2019 harvest } \\
\hline Crop (C) & 3 & ns & ns & ns & ns & $\mathrm{ns}$ & ns & ns & ns & $* *$ & $* *$ \\
\hline Inoculation (I) & 2 & ns & ns & ns & $*$ & ns & ns & ns & ns & ns & ns \\
\hline $\mathrm{C} \times \mathrm{I}$ & 6 & ns & ns & ns & ns & ns & ns & ns & ns & ns & ns \\
\hline Block & 3 & ns & ns & ns & $* *$ & $*$ & ns & ns & ns & ns & ns \\
\hline Error & 33 & - & - & - & - & - & - & - & - & - & - \\
\hline Total & 47 & - & - & - & - & - & - & - & - & - & - \\
\hline Average & - & 51.1 & 0.3 & 2.0 & 11.4 & 99.4 & 3.0 & 51.6 & 154.7 & 8.8 & 3383.5 \\
\hline \multirow[t]{2}{*}{ CV (\%) } & - & 21.46 & 27.02 & 17.82 & 22.70 & 6.01 & 0.00 & 21.60 & 21.60 & 8.92 & 11.77 \\
\hline & & \multicolumn{10}{|c|}{ 2019-2020 harvest } \\
\hline Crop (C) & 3 & ns & ns & ns & ns & $*$ & ns & ns & ns & $*$ & $* *$ \\
\hline Inoculation (I) & 2 & $* *$ & $* *$ & $*$ & $*$ & $*$ & ns & ns & ns & ns & ns \\
\hline $\mathrm{CxI}$ & 6 & ns & ns & ns & ns & ns & ns & ns & ns & ns & ns \\
\hline Block & 3 & ns & ns & ns & ns & ns & ns & ns & ns & $*$ & ns \\
\hline Error & 33 & - & - & - & - & - & - & - & - & - & - \\
\hline Total & 47 & - & - & - & - & - & - & - & - & - & - \\
\hline Average & - & 97.6 & 0.5 & 2.2 & 18.9 & 97.9 & 3.0 & 50.6 & 151.9 & 9.0 & 3568.7 \\
\hline CV (\%) & - & 15.48 & 23.32 & 22.02 & 20.18 & 3.14 & 0.00 & 9.59 & 9.59 & 5.35 & 10.05 \\
\hline
\end{tabular}

F test: ${ }^{* *}, *$ and ns - significant at $1 \%$ and $5 \%$ probability and not significant, respectively. SV: source of variation, DF: degrees of freedom, CV: coefficient of variation. 
Despite the occurrence of drought and high temperatures periods in critical stages of crop development in the 20182019 harvest and, at the beginning of the 2019-2020 harvest, low rainfall at the beginning of the 2019-2020 harvest (Figure 1 ), both crops reached the water requirement of the crop 450 to $800 \mathrm{~mm}$ per cycle (Embrapa, 2013) to obtain the maximum grain yield.

Regarding autumn-winter crops, in the 2018-2019 harvest, soybean showed higher grain yield $\left(\mathrm{kg} \mathrm{ha}^{-1}\right)$ in succession to $U$. ruziziensis established since 2013 than its cultivation after single corn and intercropped with brachiaria. The 100-grain weight $(\mathrm{g})$ of soybean was higher in succession to $U$. ruziziensis established since 2013 and 2016 than soybean in succession to the corn-brachiaria intercropping (Table 2). U. ruziziensis promotes soil cover increase either single or in intercropping with corn, preceding soybeans. Its presence protects the soil from high temperatures and helps maintain moisture. Also, Ceccon et al. (2013) affirm that the brachiaria has an aggressive root system that reaches great depths, acting as a soil conditioner, generating a greater economic return for the soybean-off-season corn succession.

In the 2019-2020 harvest, soybean had a greater 100 -grain weight (g) when cultivated after the corn-brachiaria intercropping than its cultivation in succession to single corn (Table 2). Grain yield ( $\mathrm{kg} \mathrm{ha}^{-1}$ ) was higher when soybean was grown after the corn-brachiaria and $U$. ruziziensis intercropping established since 2016 than its cultivation in succession to single corn. The yield of soybean in succession to $U$. ruziziensis established since 2013 showed no statistical difference between the cultivation systems evaluated; however, 6.5 more bags than soybean were obtained in succession to single corn (Table 2).

Soybean showed higher plant height $(\mathrm{cm})$ in the 20192020 harvest when grown in succession to the corn-brachiaria intercropping than in the other autumn-winter crops (Table 2). Vegetable residues on the soil surface, originating from corn intercropped with brachiaria cultivated in autumn-winter, may have provided a favorable microclimate for soybean growth. According to Gava et al. (2015), when soybean suffers from stresses in the important stages of development, there is a tendency to reduce height and biomass production, and even flowers and pods abortions.

Due to its high biomass production capacity with adequate soil coverage, even in low fertility areas, the Urochloa genus species are used in agriculture (Franchini et al., 2014). These species help maintain the soil organic matter content since they have a high carbon/nitrogen ratio $(\mathrm{C} / \mathrm{N})$ with a high lignin content in its constitution (Kappes \& Zancanaro, 2015), high weed suppression capacity (Lima et al., 2014) besides being easy to desiccate, favoring the soybean cultivation in succession (Ceccon \& Concenço, 2014).

In general, soybeans may have benefited from the soil structure improvement resulting from the growth of these forage roots, demonstrating that the contribution of brachiaria roots to the soybean performance is as important as the straw. These plant roots improve the soil physical quality, help in water infiltration and retention, and reduce the soil resistance to penetration (Crusciol et al., 2015).

In the 2018-2019 harvest, the co-inoculation of $B$. japonicum with $A$. brasilense provided a significant increase in the shoot dry mass (g plant ${ }^{-1}$ ). A greater number of nodules per plant $\left(\mathrm{n}^{\circ}\right.$ plant $\left.^{-1}\right)$ were found in the treatments with inoculation of $B$. japonicum and its co-inoculation with $A$. brasilense. In the 2019-2020 harvest, the inoculation of $B$. japonicum and its co-inoculation with $A$. brasilense provided a greater number of nodules per plant $\left(n^{\circ}\right.$ plant $\left.{ }^{-1}\right)$, nodules dry mass $\left(\mathrm{g} \mathrm{plant}^{-1}\right)$, and plant height $(\mathrm{cm})$ than the control treatment without inoculation. The shoot dry mass (g plant ${ }^{-1}$ ) was higher with the co-inoculation of $B$. japonicum with $A$. brasilense than the control without inoculation (Table 3 ). Positive effects of the association of Bradyrhizobium with Azospirillum were also observed by Chibeba et al. (2015) and Hungria et al. (2015b).

Associative bacteria of the Azospirillum genus are being used in agriculture, as they stimulate plant hormone production (auxins, cytokinins, gibberellins, and ethylene) that promote plant growth and development (Gitti, 2016). This stimulating effect may be related to the values observed in Table 3, where the co-inoculation of B. japonicum with $A$. brasilense provided a greater shoot dry mass (g plant ${ }^{-1}$ ) in the 2018-2019 harvest. In the $2019 / 2020$ harvest, this stimulation provided the increase in the number of nodules per plant $\left(n^{\circ}\right.$ plant $\left.^{-1}\right)$, nodules dry mass $\left(g_{\text {plant }}^{-1}\right)$, shoot dry mass ( $g$ plant $\left.^{-1}\right)$, and plant height $(\mathrm{cm})$ compared to inoculations with $B$. japonicum and $A$. brasilense and the control treatment without inoculation.

Soybean producers have increasingly used co-inoculation of bacteria of the Bradyrhizobium genus with plant growth-

Table 2. Plant height (PH), the 100-grain weight (100W), and grain yield (YIELD) of soybean BRS 1003 cultivar in succession to autumn-winter crops in the 2018-2019 and 2019-2020 harvests. Dourados, MS. 2020.

\begin{tabular}{lccccc}
\hline \multirow{2}{*}{ Autumn-Winter Crops } & \multicolumn{2}{c}{ 2018-2019 harvest } & \multicolumn{2}{c}{ 2019-2020 harvest } \\
\cline { 2 - 6 } & $\mathbf{1 0 0 W}(\mathbf{g})$ & YIELD $\left(\mathbf{k g ~ h a}^{-\mathbf{1}}\right)$ & PH $(\mathbf{c m})$ & 100W (g) & YIELD (kg ha-1) \\
\hline Single Corn & $8.7 \mathrm{ab}$ & $3098.8 \mathrm{bc}$ & $97.5 \mathrm{~b}$ & $8.7 \mathrm{~b}$ & $3241.4 \mathrm{~b}$ \\
Corn-brachiaria intercropping & $8.0 \mathrm{~b}$ & $3012.1 \mathrm{c}$ & $100.9 \mathrm{a}$ & $9.4 \mathrm{a}$ & $3742.9 \mathrm{a}$ \\
Urochloa ruziziensis 2013 & $9.5 \mathrm{a}$ & $3905.2 \mathrm{a}$ & $97.0 \mathrm{~b}$ & $9.1 \mathrm{ab}$ & $3635.5 \mathrm{ab}$ \\
Urochloa ruziziensis 2016 & $9.1 \mathrm{a}$ & $3518.0 \mathrm{ab}$ & $96.1 \mathrm{~b}$ & $8.9 \mathrm{ab}$ & $3654.9 \mathrm{a}$ \\
Average & 8.8 & 3383.5 & 97.9 & 9.0 & 3568.7 \\
Coefficient of variation (\%) & 8.92 & 11.77 & 3.14 & 5.35 & 10.05 \\
\hline
\end{tabular}

Means followed by equal letters do not differ by the Tukey test, $p \geq 0.05$. 
Table 3. Number of nodules per plant (NNP), nodule dry mass (NDM), shoot dry mass (SDM), plant height (PH) of soybean BRS 1003 cultivar inoculated with Bradyrhizobium japonicum and Azospirillum brasilense in the 2018-2019 and 2019-2020 harvests. Dourados, MS. 2020.

\begin{tabular}{|c|c|c|c|c|c|}
\hline \multirow{2}{*}{ Inoculation } & \multirow{2}{*}{$\begin{array}{l}\text { 2018-2019 harvest } \\
\text { SDM (g plant }{ }^{1} \text { ) }\end{array}$} & \multicolumn{4}{|c|}{ 2019-2020 harvest } \\
\hline & & NNP $\left(n^{\circ}\right.$ plant $\left.^{-1}\right)$ & NDM (g plant $\left.{ }^{-1}\right)$ & SDM (g plant $\left.{ }^{-1}\right)$ & $\mathrm{PH}(\mathrm{cm})$ \\
\hline Without inoculant & $10.5 \mathrm{~b}$ & $78.4 \mathrm{~b}$ & $0.4 \mathrm{~b}$ & $16.6 \mathrm{~b}$ & $95.9 \mathrm{~b}$ \\
\hline B. japonicum & $10.6 \mathrm{~b}$ & $105.1 \mathrm{a}$ & $0.5 \mathrm{a}$ & $19.6 \mathrm{ab}$ & 98.8 a \\
\hline B. japonicum + A. brasilense & $13.0 \mathrm{a}$ & $109.4 \mathrm{a}$ & $0.6 \mathrm{a}$ & $20.4 \mathrm{a}$ & 98.9 a \\
\hline Average & 11.4 & 97.6 & 0.5 & 18.9 & 97.9 \\
\hline Coefficient of variation (\%) & 22.70 & 15.48 & 23.32 & 20.18 & 3.14 \\
\hline
\end{tabular}

Means followed by equal letters do not differ by the Tukey test, $p \geq 0.05$.

promoting bacteria of the Azospirillum genus to enhance nodulation, promote greater root growth (Zeffa et al., 2020; Rondina et al., 2020), in addition to increasing grain yield by up to $16.1 \%$, compared to inoculation with only $B$. japonicum (Hungria et al., 2015b), being economically viable and environmentally sustainable.

During the experiment, the climate was marked by periods of drought and high temperatures, characteristic of the region. Therefore, the importance of introducing brachiaria in autumn-winter crops is evident for the reduction of unfavorable climatic effects on soybean in succession, under the studied edaphoclimatic conditions.

\section{Conclusions}

Urochloa ruziziensis, cultivated in autumn-winter, contributes to the increase in grain yield of soybean grown in succession.

Co-inoculation of Bradyrhizobium japonicum with Azospirillum brasilense complements biological nitrogen fixation (BNF), contributing to soybean development.

\section{Acknowledgments}

ThThis work was carried out with the financial support of the Coordenação de Aperfeiçoamento de Pessoal de Nível Superior - Brazil (CAPES) - Financing Code 001 and Empresa Brasileira de Pesquisa Agropecuária (EMBRAPA/CPAO).

\section{Compliance with Ethical Standards}

Author contributions: Conceptualization: GC; Data curation: DPC, RF; Formal analysis: CMGS, DPC; Funding acquisition: GC; Investigation: DPC, RF; Methodology: GC, RF; Project administration: GC; Resources: CMGS; Software: RF; Supervision: GC; Validation: DPC, GC; Visualization: DPC, GC; Writing - original draft: DPC, GC; Writing - review \& editing: DPC, GC.

Conflict of interest: The authors declared that there is no possible conflict of interest (professional or financial) that may influence the article.

Funding: Coordenação de Aperfeiçoamento de Pessoal de Nível Superior - Brasil (CAPES) - Finance Code 001 and Empresa Brasileira de Pesquisa Agropecuária (EMBRAPA/CPAO).

\section{Literature Cited}

Bashan, Y.; De-Bashan, L.E.; Prabhu, S.R.; Hernandez, J.P. Advances in plant growth-promoting bacterial inoculant technology: formulations and practical perspectives (1998-2013). Plant and Soil, v. 378, n.1-2, p.1-33, 2014. https://doi.org/10.1007/s11104013-1956-x.

Battisti, R.; Sentelhas, P.C.; Pascoalino, J.A.L.; Sako, H.; De Sá Dantas, JP; Moraes, M.F. Soybean yield gap in the areas of yield contest in Brazil. International Journal of Plant Production, v. 12, p. 159168, 2018. https://doi.org/10.1007/s42106-018-0016-0.

Ceccon, G.; Concenço, G. Produtividade de massa e dessecação de forrageiras perenes para integração lavoura-pecuária. Planta Daninha, v. 32, n. 2, p. 319-326, 2014. https://doi.org/10.1590/ S0100-83582014000200009.

Ceccon, G.; Silva, J.F.; Neto, A.L.N.; Makino, P.A.; Santos, A. Produtividade de milho safrinha em espaçamento reduzido consorciado com populações de plantas de Brachiaria ruziziensis. Revista Brasileira de Milho e Sorgo, v. 13, n. 3, p. 326-335, 2014. https://doi.org/10.18512/1980-6477/rbms.v13n3p326-335.

Ceccon, G.; Staut, L.A.; Sagrilo, E.; Machado, L.A.Z.; Nunes, D.P.; Alves, V.B. Legumes and forage species sole or intercropped with corn in soybean-corn succession in Midwestern Brazil. Revista Brasileira de Ciência do Solo, v. 37, n. 1, p. 204-212, 2013. https:// doi.org/10.1590/S0100-06832013000100021.

Chibeba, A.M.; Guimarães, M.F.; Brito, O.R.; Nogueira, M.A.; Araujo, R.S.; Hungria, M. Co-inoculation of soybean with Bradyrhizobium and Azospirillum promotes early nodulation. American Journal of Plant Sciences, v. 6, n.10, p. 1641-1649, 2015. https://doi. org/10.4236/ajps.2015.610164.

Crusciol, C.A.C.; Nascente, A.S; Borghi, E.; Soratto, R.P; Martins, P.O. Melhorando a fertilidade do solo e o rendimento das culturas em uma região tropical com cobertura de capim-bravo. Agronomy Journal, v. 107, n.6, p. 2271-2280, 2015. https://doi.org/10.2134/ agronj14.0603.

Empresa Brasileira de Pesquisa Agropecuária - Embrapa. Embrapa Soja. Soluções tecnológicas. Soja - BRS 1003IPRO. Londrina: Embrapa Soja, 2016. https://www.embrapa.br/busca-desolucoes-tecnologicas/-/produto-servico/2917/soja---brs1003ipro. 19 Mar. 2020.

Empresa Brasileira de Pesquisa Agropecuária - Embrapa. Guia clima. Dourados/MS. Dourados: Embrapa Agropecuária Oeste, 2020. https://clima.cpao.embrapa.br/?lc=site/banco-dados/base_ dados. 20 Mar. 2020. 
Empresa Brasileira de Pesquisa Agropecuária - Embrapa. Tecnologias de produção de soja: Região Central do Brasil 2012 e 2013. Londrina: Embrapa Soja, 2011. 261p. (Embrapa Soja. Sistemas de Produção, 15). https://ainfo.cnptia.embrapa.br/digital/ bitstream/item/44954/1/TEC.-PROD.15.pdf. 05 Apr. 2020.

Franchini, J.C.; Balbinot Junior, AA; Debiasi, H.; Conte, O. Soybean performance as affected by desiccation time of Urochloa ruziziensis and grazing pressures. Revista Ciência Agronômica, v. 45 , n. 5, p.999-1005, 2014. https://doi.org/10.1590/S180666902014000500015.

Gava, R.; Frizzone, J.A.; Snyder, R.L.; Jose, J.V.; Fraga Junior, E.F.; Perboni, A. Estresse hídrico em diferentes fases da cultura da soja. Revista Brasileira de Agricultura Irrigada, Fortaleza, v. 9, n. 6, p. 349-359, 2015. https://doi.org/10.7127/rbai.v9n600368.

Gitti, D.C.; Inoculação e coinoculação na cultura da soja. In: Melotto, A.M.; Lourenção, A.L.F.; Gitti, D.C.; Grigolli, J.F.J. (Eds.). Tecnologia e produção: safra 2015/2016. 1.ed. Curitiba: Midiograf, 2016. v. 1, p. 15-23.

Hungria, M.; Marco, A.N.; Ricardo, S.A. Alternative methods of soybean inoculation to overcome adverse conditions at sowing. African Journal of Agricultural Research, v. 10, n. 23, p. 23292338, 2015a. https://doi.org/10.5897/AJAR2014.8687.

Hungria, M.; Nogueira, M.A.; Araújo, R.S. Soybean seed coinoculation with Bradyrhizobium spp. and Azospirillum brasilense: a new biotechnological tool to improve yield and sustainability. American Journal of Plant Sciences, v. 6, n.6, p. 811-817, 2015b. https://doi.org/10.4236/ajps.2015.66087.

Kappes, C.; Zancanaro, L. Sistemas de consórcios de braquiária e de crotalárias com a cultura do milho. Revista Brasileira de Milho e Sorgo, v. 14, n. 2, p. 219-234, 2015. https://doi. org/10.18512/1980-6477/rbms.v14n2p219-234

Lima, S.F.; Timossi, P.C.; Almeida, D.P.; Silva, U.R. Palhada de braquiária ruziziensis na supressão de plantas daninhas na cultura da soja. Revista Agrarian, v. 7, n. 26, p. 541-551, 2014. http:// ojs.ufgd.edu.br/index.php/agrarian/article/view/3110/1982. 25 Mar. 2020

Ministério da Agricultura, Pecuária e Abastecimento - Mapa. Instrução Normativa № 13, de 24 de março de 2011. Aprova as normas sobre especificações, garantias, registro, embalagem e rotulagem dos inoculantes destinados à agricultura, bem como as relações dos micro-organismos autorizados e recomendados para produção de inoculantes no Brasil. Diário Oficial da União, v.198, n.58, seção 1, p. 3-7, 2011. https://www.gov.br/ agricultura/pt-br/assuntos/insumos-agropecuarios/insumosagricolas/fertilizantes/legislacao/in-sda-13-de-24-03-2011inoculantes.pdf. 29 Mar. 2020.

Rondina, A.B.L.; Sanzovo, A.W.S.; Guimaraes, G.S.; Wendling, J.R.; Nogueira, M.A.; Hungria, M. Changes in root morphological traits in soybean co-inoculated with Bradyrhizobium spp. and Azospirillum brasilense or treated with $A$. brasilense exudates. Biology and Fertility of Soils, v. 56, p. 537-549, 2020. https://doi. org/10.1007/s00374-020-01453-0.

Santos, H.G.; Jacomine, P.K.T.; Anjos, L.H.C.; Oliveira, V.Á.; Lumbreras, J.F.; Coelho, M.R.; Almeida, J.A.; Araújo Filho, J.C.; Oliveira, J.B.; Cunha, T.J.F. Sistema brasileiro de classificação de solos. 5.ed. Rio de Janeiro: Embrapa, 2018. 187p.

Sentelhas, P.C.; Battisti, R.; Câmara, G.M.S.; Farias, J.R.B.; Hampf, A.C.; Nendel, C. The soybean yield gap in Brazil - magnitude, causes, and possible solutions for sustainable production. Journal of Agricultural Science, v. 153, p. 1394-1411, 2015. https://doi. org/10.1017/s0021859615000313.

United States Department of Agriculture - USDA. Soil taxonomy. A basic system of soil classification for making and interpreting soil survey. 2.ed. Washington D. C.: Soil Survey Staff; Natural Resources Conservation Service - NRCS; United States Department of Agriculture - USDA, 1999. 886p. https://www. nrcs.usda.gov/wps/portal/nrcs/main/soils/survey/class/ taxonomy. 12 Feb. 2021.

Zeffa, D.M.; Koltun, A.; Goncalves, L.S.A.; Oliveira, A.L.M.; Nunes, M.P.; Canteri, M.G. Effects of plant growth-promoting rhizobacteria on co-inoculation with Bradyrhizobium in soybean crop: a metaanalysis of studies from 1987 to 2018. PeerJ, v. 8, e7995, 2020. https://doi.org/10.7717/peerj.7995.

Zuffo, A.M.; Rezende, P.M.; Bruzi, A.T.; Ribeiro, A.B.M.; Zambiazzi, E.V.; Soares, I.O.; Vilela, N.J.D.; Bianchi, M.C. Soybean cultivars agronomic performance and yield according to doses of Azospirillum brasilense applied to leaves. Australian Journal of Crop Science, v. 10, n.4, p. 579-583, 2016. https://doi. org/10.21475/ajcs.2016.10.04.p7554x. 